\title{
A PROPOSAL FOR AN ASSESSMENT METHOD OF THE DYNAMIC RESISTANCE OF CONCRETE SLAB VIADUCTS SUBJECTED TO IMPACT LOADS CAUSED BY MINING TREMORS
}

\begin{abstract}
The article presents a method for assessing dynamic resistance of existing reinforced concrete slab road viaducts subjected to mining tremors. For this purpose there are formulated six criteria to determine the maximum permissible value of the component ground vibrations $\left(a_{x, \text { dop }}, a_{y, d o p}, a_{z, \text { dop }}\right)$. Within each criterion, a reference is made to the most critical components, for which for which the Author has formulated strength and kinematic conditions, reflecting the behaviour of the structure under dynamic excitation caused by mining tremor. The permissible range of structural behaviour was set by comparing the effects of load combinations adopted at the design stage with a seismic combination proposed in [12]. In the field of dynamic analysis the response spectrum method was used, taking into account the guidelines for the adaptation of Eurocode 8 for the calculation the response of construction to the influence of mining tremors. Finally, in accordance with the established procedure calculations were carried out and and results are presented for a sample reinforced concrete slab road viaduct.
\end{abstract}

Key words: viaducts, reinforced concrete structures, dynamic resistance, mining impacts, tremors

\section{Introduction}

In engineering practice, it is often necessary to assess the resistance of the existing building structures to additional loads which occur during their use, and which have not been taken into consideration at the design stage. This is the case of a great number of the existing bridges located in mining areas, where paraseismic impacts occur $[4,8]$.

The assessment of the resistance of the existing bridge structures, which is to be consistent with the current guidelines for the combination of the loads, is a complex issue.

\footnotetext{
${ }^{1}$ Janusz Rusek, Department of Engineering Surveying and Civil Engineering, Faculty of Mining Surveying and Environmental Engineering AGH University of Science and Technology, al. Mickiewicza 30-059 Cracow, Poland; tel. 48126172274, rusek@agh.edu.pl
} 
This is due to the need to refer to the assumptions made at the design stage, and resulting from the directives of the obsolete standards, to the current criteria dictated by the Eurocodes.

Moreover, when assessing the influence of ground vibrations caused by mining tremors on bridge structures, it is necessary to determine the resistance of the structure, not only to check the condition of the load-bearing capacity with strictly predetermined value of the load. The resistance of the structure is represented at this point by the maximum value of the parameter describing ground vibrations (acceleration or velocity) which the structure can carry, without reducing the safety criteria defined by the current design standards. Such resistance, therefore, determines the extent of the limit performance of the structure subjected to additional dynamic loads.

Another difficulty in this case is the uncertainty in relation to the material parameters adopted at the design stage. With respect to the reinforced concrete bridge structures, the problem frequently concerns the actual degree of reinforcement of their supporting elements and the effective load-bearing capacity of the bearings used.

Paper presents a procedure for determining the dynamic resistance for the existing bridge structures subjected to additional paraseismic influences. The basis for the study was a preliminary methodology for assessing the resistance of bridge structures, described in [4]. This approach has introduced some changes to the subject, relative to the predetermined criteria to such extent, so that the proposed approach could makes it possible to the determination of the dynamic resistance of bridge structures carried out in the conditions of uncertainty.

\section{Research methodology}

The determination of the dynamic resistance of a bridge structure, or of the additional extent of acceptable performance of the existing structure in the case of a tremor, involves identifying a certain buffer included in the area of the original design assumptions, where it is possible to allow for additional load on the structure.

The procedure for the assessment of resistance, which is proposed in this study, involves the comparison of the effects of the combination of the loads acting on the structure from the design stage determined according to [11 and 15], with the effects of the seismic combination of the loads dictated by the standard PN-EN 1990:2004 [12].

In general, this procedure requires the following:

- the assumptions about the technical condition of the structure which is at least satisfactory,

- the assumption about meeting the conditions for the load-bearing capacity of the structure of all the load combinations adopted at the design stage, 
- the identification of the potential scenarios of the structure performance under dynamic loads which may result in the increased effort of its components or cause a scheme of its performance which was not predicted during the design stage,

- the combination of the predicted effects of the dynamic excitation, resulting from the seismic combination with the equivalent effects (as to the individual elements and directions of the influences) of the combinations adopted at the design stage,

- the formulation of the dependencies allowing one to identify the maximum value of the components characterizing the dynamic excitation (acceleration or velocity of ground vibration at the location of the structure) in individual directions.

The combinations adopted at the design stage according to [11 and 15], exhaust the range of possible load situations, where a margin allowing for the carrying of additional dynamic influences by the existing bridge can be found. These combinations are mutually separate, and therefore it is possible to compare the effects of the combination of the loads adopted at the design stage with the effects of the seismic combination. Such a combination allows to specify the limit values characterizing the ground vibrations induced by mining tremors at the location of the object.

According to [12], the STR limit state criterion, determining the scenario for the structural damage due to the excessive effort of the cross-section or the strain of the load-bearing elements, is expressed by the relationship:

$$
\boldsymbol{E}_{\boldsymbol{d}} \leq \boldsymbol{R}_{\boldsymbol{d}}
$$

where: $\boldsymbol{E}_{\boldsymbol{d}^{-}}$the design value of the effect of the influence (internal force, strain, bending, rotation, etc.)

$\boldsymbol{R}_{\boldsymbol{d}}$ - the design value of the load-bearing capacity.

Assuming the fact that the bridge structure which was put into operation meets the requirements set at the design stage, it can be concluded that the conditions regarding the load-bearing capacity are also met for any required standardized combination of the loads according to [11]:

$$
E_{d}^{P N} \leq R_{d}^{P N}
$$

where: $\boldsymbol{E}_{\boldsymbol{d}}^{\boldsymbol{P N}}$ - the design value of the influence effect (internal force, strain, bending, rotation, etc.) for a given combination of the loads adopted at the design stage according to [11]

$\boldsymbol{R}_{\boldsymbol{d}}^{\boldsymbol{P N}}$ - the design value of the load-bearing capacity from the design stage corresponding to a given combination of the loads according to [11].

It is known that the analysis of the effects of influences for each combination of the loads allows one to design reliable cross-sections of the structural elements of a specific object. If there is additional load applied to the structure 
by the inertial forces induced by the vibrations of the ground, these crosssections require to be verified in the context of a seismic combination according to [12]. Because the combinations of the loads are separate design situations, and referring to the earlier assumption about meeting the requirements of the loadbearing capacity for the design stage, the load-bearing criterion for a specific element for the seismic combination may be formulated so that:

$$
E_{d}^{S E} \leq R_{d}^{P N}
$$

where: $\boldsymbol{E}_{\boldsymbol{d}}^{\boldsymbol{S} \boldsymbol{E}}$ - the design value of the effect of seismic impacts

$\boldsymbol{R}_{\boldsymbol{d}}^{\boldsymbol{P N}}$ - the design value of the load-bearing capacity from the design stage corresponding to a specific combination of the loads according to [11].

On the other hand, according to (2), assuming full use of the load-bearing capacity with respect to the effects for a given design situation:

$$
E_{d}^{P N}=R_{d}^{P N}
$$

equation (3) can be converted to (5):

$$
E_{d}^{S E} \leq E_{d}^{P N}
$$

Such formulation of the problem allows for the verification of the loadbearing capacity of the existing structure only on the grounds of the effects of the combinations of the loads adopted for individual elements of the structure. Knowing, for example, that the degree of reinforcement of the reinforced concrete elements corresponds closely to the effects of the combinations of the loads adopted at the design stage, it is possible to skip the detailed analysis of the loadbearing capacity of a given reinforced concrete cross-section when analyzing the seismic combination. In the situation of determining the minimum load-bearing capacity of the bearings, the procedure may be similar. In general, this leads to a significant simplification of the procedure for assessing the dynamic resistance and enables the analysis of the structure for which the information about its loadbearing elements is drawn only from the approximations based e.g. on locally uncovered parts of the reinforcement or the assessment of the technical condition of the bearings.

\section{The conditions for the dynamic resistance of bridge structures}

In the conditions presented below, the principle was introduced that for the combination from the design stage, the extent of the additional loads which are taken into account will be minimized, and in the case of the seismic combination, it will be expanded as much as possible. If it was necessary to take into consideration more than one combination from the design stage for a specific 
condition, then the one which resulted in the occurrence of the effects of the smallest values in the construction was selected (i.e. cross-sectional forces, support reactions or displacements).

\subsection{The strength condition of the load-bearing capacity of the spans}

The condition of the load-bearing capacity of the spans was formulated with regard to the situation in which the moments and cross-sectional forces in reliable cross-sections of the spans were analysed depending on the static force diagram of the object (c.f. Fig. 1). Under this condition, the limit value of the vertical component of the acceleration of ground vibrations $a_{z, d o p}{ }^{W 1}$ is determined.

Tabela 1. Zestawienie parametrów przyjmowanych do obliczeń w ocenie odporności dynamicznej dla kryterium wytężeniowego warunku nośności przęseł.

Table 1. A list of the parameters adopted for the calculations in assessing the dynamic resistance for the strength criterion of the load-bearing capacity of the spans

\begin{tabular}{|c|c|}
\hline $\begin{array}{l}\text { The combination of design stage by } \\
\text { [11] }\end{array}$ & $\sum_{i=1}^{m} 1,2 G_{k, i}+1,3 Q_{T S}$ \\
\hline Seismic combination of loads by [12] & $\sum_{i=1}^{m} G_{k, i}+A_{e d}$ \\
\hline The final form of the condition & $M^{P N}\left(\sum_{i=1}^{m} 1,2 G_{k, i}+1,3 Q_{T S}\right) \geq M^{S E}\left(\sum_{i=1}^{m} G_{k, i}+A_{e d}\right)$ \\
\hline $\begin{array}{l}G_{k, i}-\text { self-weight structural components of } \mathrm{t} \\
A_{e d}-\text { design value of the seismic impact } \\
Q_{T S}-\text { value of traffic load from design stage } \\
M^{P N}, M^{S E} \text { - bending moments determined fo }\end{array}$ & bridge and equipment \\
\hline
\end{tabular}

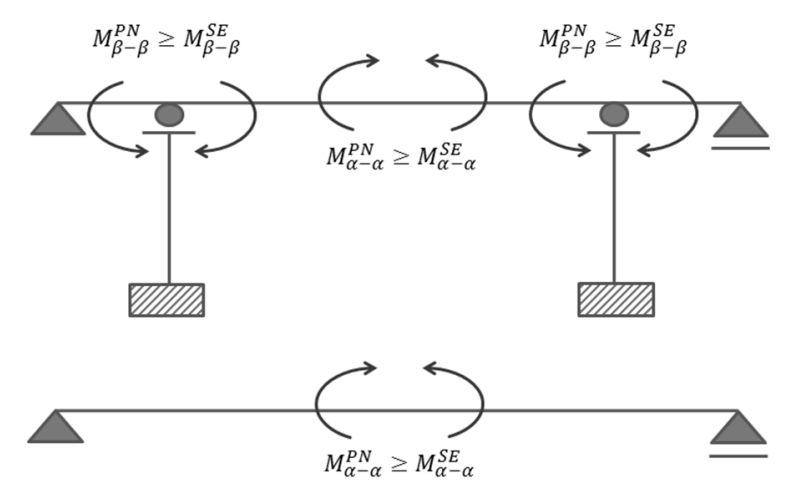

Rys. 1. Schemat wskazujący przekroje miarodajne przyjmowane do oceny odporności dynamicznej wg wytężeniowego kryterium nośności przęseł

Fig. 1. A diagram illustrating the reliable cross-sections adopted for the assessment of the dynamic resistance for the strength criterion of the load-bearing capacity of the spans 


\subsection{The condition of the load-bearing capacity of the fixed bearings and the bearings sliding in one direction (leading)}

The condition of the load-bearing capacity of the bearings is designed for three separate design situations. Each of them reflects the bearing performance in a given direction (x, y, and z) (c.f. Fig. 2). For each of them, reliable standard combinations from the design stage were determined [6,10], and they were combined with the effects of the seismic combination (c.f. Tab. 2). The result is the determination of the limit values of the components of the acceleration of ground vibrations: $a_{x, d o p}{ }^{\mathrm{W} 2}, a_{y, d o p}{ }^{\mathrm{W} 2} a_{z, d o p}{ }^{\mathrm{W} 2}$.

Tabela 2. Zestawienie parametrów przyjmowanych do obliczeń w ocenie odporności dynamicznej dla kryterium nośności łożysk stałych i prowadzących

Table 2. A list of the parameters adopted for calculations in assessing the dynamic resistance for the criterion of the load-bearing capacity of fixed and leading bearings

\begin{tabular}{|c|c|c|}
\hline \multicolumn{3}{|c|}{ Vertical direction- $z$} \\
\hline The combination of design stage by [11] & \multicolumn{2}{|c|}{$\sum_{i=1}^{m} 1,2 G_{k, i}+1,3 Q_{T S}$} \\
\hline Seismic combination of loads by [12] & \multicolumn{2}{|c|}{$\sum_{i=1}^{m} G_{k, i}+A_{e d}$} \\
\hline The final form of the condition & \multicolumn{2}{|c|}{$R^{P N}\left(\sum_{i=1}^{m} 1,2 G_{k, i}+1,3 Q_{T S}\right) \geq R^{S E}\left(\sum_{i=1}^{m} G_{k, i}+A_{e d}\right)$} \\
\hline \multicolumn{3}{|c|}{ Horizontal direction- $x$ (parallel to the axis of the object) } \\
\hline \multicolumn{3}{|c|}{ The combination of design stage by [11 and 15] } \\
\hline \multicolumn{2}{|c|}{$\begin{array}{l}\text { basic load: braking and acceleration forces of car fleet } \boldsymbol{Q}_{1 k} \\
\text { additional load: thermal load span } \boldsymbol{T}_{k}\end{array}$} & $1,3 Q_{1 k}+0.9 \cdot 1,2 T_{k}$ \\
\hline \multicolumn{3}{|c|}{ Corresponding seismic combination by [12 and 13] } \\
\hline \multicolumn{3}{|c|}{$A_{e d}+0,5 T_{k}$} \\
\hline \multicolumn{3}{|l|}{ The final form of the condition } \\
\hline \multicolumn{3}{|c|}{$R^{P N}\left(1,3 Q_{1 k}+0.9 \cdot 1,2 T_{k}\right) \geq R^{S E}\left(A_{e d}+0,5 T_{k}\right)$} \\
\hline \multicolumn{3}{|c|}{ Horizontal direction- $x$ (perpendicular to the axis of the object) } \\
\hline \multicolumn{3}{|c|}{ The combination of design stage by [11 and 15$]$} \\
\hline \multicolumn{2}{|c|}{$\begin{array}{l}\text { basic load: the forces of a side impact of the elements of the bridge } U_{k d} \\
\text { additional load: wind load acting on the vehicle fleet } \boldsymbol{W}_{k s}\end{array}$} & $1,3 U_{k d}+0,9 \cdot 1,2 W_{k s}$ \\
\hline \multicolumn{3}{|c|}{ Corresponding seismic combination by [12 and 13] } \\
\hline \multicolumn{3}{|c|}{$A_{e d}$} \\
\hline \multicolumn{3}{|l|}{ The final form of the condition } \\
\hline \multicolumn{3}{|c|}{$R^{P N}\left(1,3 U_{k d}+0,9 \cdot 1,2 W_{k s}\right) \geq R^{S E}\left(A_{e d}\right)$} \\
\hline \multicolumn{3}{|c|}{$\begin{array}{l}G_{k, i}-\text { self-weight structural components of the bridge and equipment } \\
A_{e d} \text { - design value of the seismic impact } \\
T_{k} \text { - characteristic value of the thermal load of the span } \\
Q_{i k} \text { - the characteristic value of the load caused by forces of braking or acceleration of the rolling stock } \\
Q_{T S} \text { - value of traffic load from design stage } \\
W_{k s}-\text { characteristic value of wind load } \\
U_{k d}-\text { the characteristic value of the load caused by a side impact on the elements of a bridge } \\
R^{P N}, R^{S E} \text { - reaction forces determined for the combination of design stage }(P N) \text { and seismic combination } \\
(S E)\end{array}$} \\
\hline
\end{tabular}


fixed bearing - directions $\mathrm{x}$ and $\mathrm{y}$
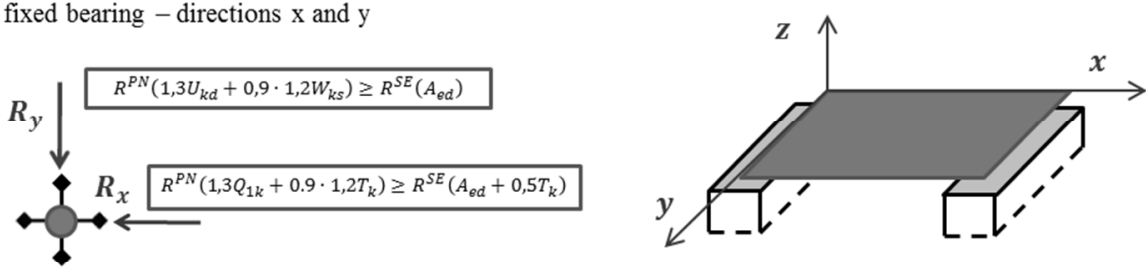

unidirectional movable bearing - directions $\mathrm{x}$ and $\mathrm{y}$

Vertical direction $z$
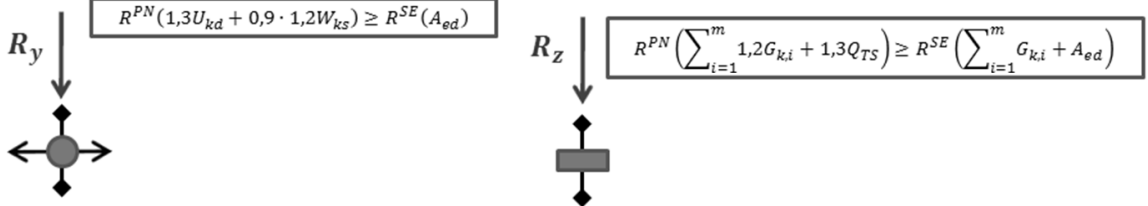

Rys. 2. Schemat obrazujący sposób ustalania wartości reakcji podporowych dla kryterium związanego z nośnością łożysk stałych i prowadzących

Fig. 2. A diagram illustrating the method of determining the values of support reaction forces for the criterion relating to the load-bearing capacity of fixed and leading bearings

\subsection{The condition of the contact between the support and the span}

This condition imposes a limit on the vertical component of the acceleration of ground vibrations, so as to prevent the situation in which, as a result of dynamic excitation, the span will be relieved and will lose the required value of the pressure to the support (c.f. Fig. 3). In contrast to the other conditions, this criterion does not correspond to any design situation from the design stage. That is why it was individually designed and consists of the combination of the reduced contribution of the permanent loads in accordance with [12], and the effect of the dynamic influence in the vertical direction. The result of taking this criterion into account is the limit value of the vertical component of the acceleration of ground vibrations $a_{z, d o p}$ W3 .

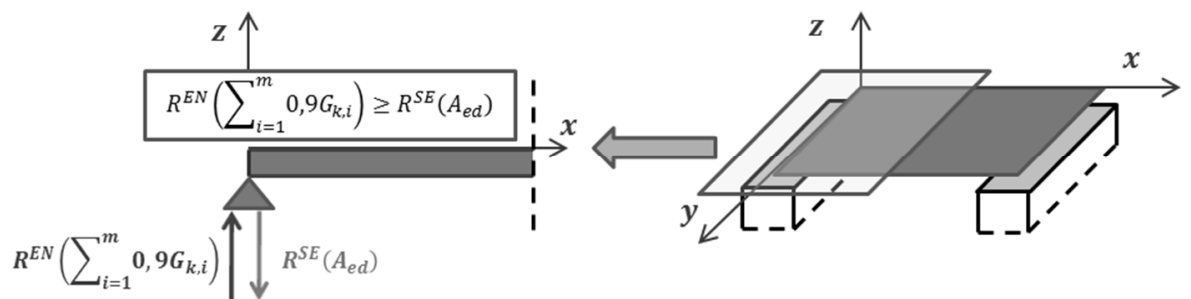

Rys. 3. Schemat obrazujący sposób ustalania kryterialnych wartości reakcji podporowych dla warunku kontaktu podpory z przęsłem

Fig. 3. A diagram illustrating the method of determining the criterion values of the support reactions for the condition of the contact between the support and the span 
Tabela 3. Zestawienie parametrów przyjmowanych do obliczeń w ocenie odporności dynamicznej dla warunku kontaktu podpory z przęsłem

Table 3. A list of the parameters adopted for the calculations in assessing the dynamic resistance for the condition of the contact between the support and the span

\begin{tabular}{|l|c|}
\hline The final form of the condition & $R^{E N}\left(\sum_{i=1}^{m} 0,9 G_{k, i}\right) \geq R^{S E}\left(A_{e d}\right)$ \\
\hline$G_{k, i}-$ self-weight structural components of the bridge and equipment \\
$A_{e d}-$ design value of the seismic impact \\
$R^{E N}, R^{S E}-$ reaction forces determined form STR combination by [12] and seismic combination (SE) \\
\hline
\end{tabular}

\subsection{The condition limiting the friction force for the sliding bearings}

This is another condition limiting the value of the vertical component of the acceleration of ground vibrations $a_{z, d o p}{ }^{W 4}$. It limits the value of support reactions so that the pressure caused by the additional dynamic excitation, with the impulse in the form of the action of temperature or horizontal forces from braking or accelerating vehicles, did not generate friction forces with the values greater than those adopted at the design stage (c.f. Fig. 4).

Tabela 4. Zestawienie parametrów przyjmowanych do obliczeń w ocenie odporności dynamicznej dla warunku ograniczającego siłę tarcia w łożyskach przesuwnych

Table 4. A list of the parameters adopted for the calculations in assessing the dynamic resistance for the condition limiting friction forces in sliding bearings

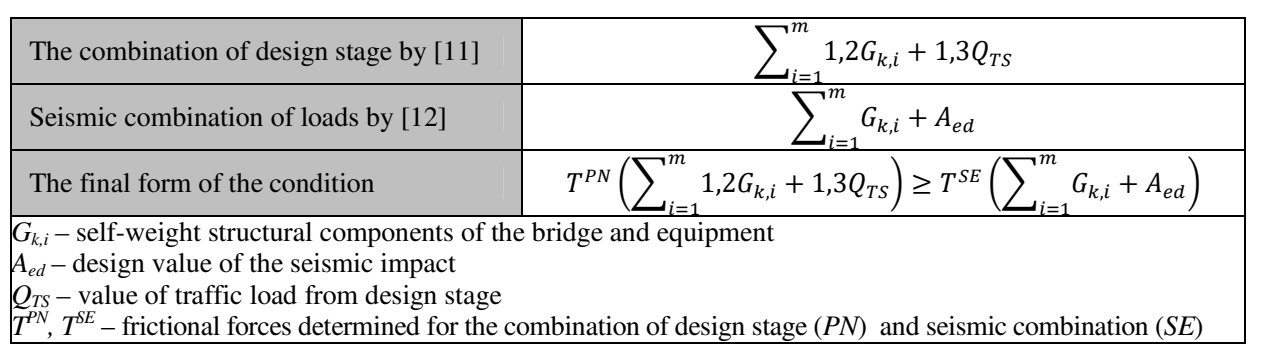

multidirectional movable bearing - directions $\mathrm{x}$ and $\mathrm{y}$

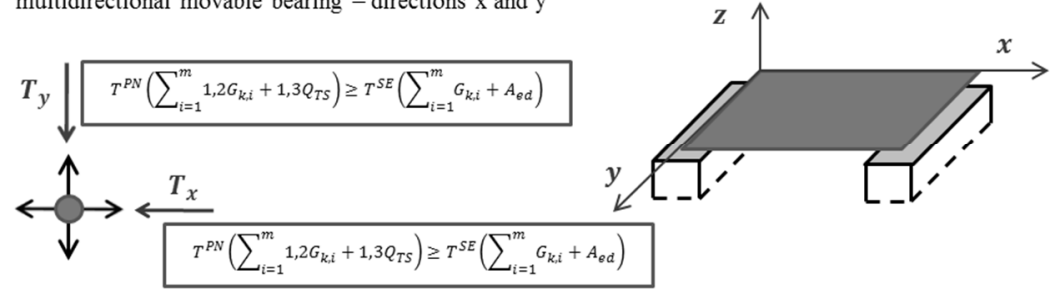

unidirectional movable bearing - direction $\mathrm{x}$

Rys. 4. Schemat obrazujący sposób ustalania kryterialnych wartość sił tarcia dla łożysk przesuwnych

Fig. 4. A diagram illustrating the method of determining the criterion values of friction forces for sliding bearings 


\subsection{The condition limiting the sliding of the sliding bearings}

This condition introduces further limitations to the values of the horizontal components of the ground vibrations in the direction longitudinal to the axis of the object: $a_{x, d o p}$. It is assumed that the effects of the loads causing displacements of the span in the sliding bearings, adopted at the design stage in accordance with [15], generate displacement values greater than, or equal to, those generated by the structure under the loads resulting from the seismic combination (c.f. Fig. 5). Under this condition, it is assumed that there is no possibility to displace the span in the direction perpendicular to the axis of the object, since it would mean the exceeding of the load-bearing capacity of the leading bearings (in the y-direction) for which, inter alia, the condition of the load-bearing capacity of the leading bearing was formulated (c.f. 3.2).

Tabela 3. Zestawienie parametrów przyjmowanych do obliczeń w ocenie odporności dynamicznej dla warunku ograniczającego przesuw łożysk ruchomych

Table 3. A list of the parameters adopted for the calculations in assessing the dynamic resistance for the condition limiting the displacement of the sliding bearings

\begin{tabular}{|c|c|}
\hline \multicolumn{2}{|c|}{ Horizontal direction- $x$ (parallel to the axis of the object) } \\
\hline \multicolumn{2}{|l|}{ The combination of design stage by [11and 15] } \\
\hline $\begin{array}{l}\text { basic load: braking and acceleration forces of car } \\
\text { fleet } Q_{1 k} \\
\text { additional load: thermal load span } \boldsymbol{T}_{k}\end{array}$ & $1,3 Q_{1 k}+0.9 \cdot 1,2 T_{k}$ \\
\hline Corresponding seismic combination by [12 and 13] & $A_{e d}+0,5 T_{k}$ \\
\hline The final form of the condition & $U^{P N}\left(1,3 Q_{1 k}+0.9 \cdot 1,2 T_{k}\right) \geq U^{S E}\left(A_{e d}+0,5 T_{k}\right)$ \\
\hline \multicolumn{2}{|c|}{$\begin{array}{l}G_{k, i}-\text { self-weight structural components of the bridge and equipment } \\
A_{e d}-\text { design value of the seismic impact } \\
T_{k}-\text { characteristic value of the thermal load of the span } \\
Q_{i k}-\text { the characteristic value of the load caused by forces of braking or acceleration of the rolling stock } \\
U^{P N}, U^{S E}-\text { horizontal displacements of bearings determined for the combination of design stage }{ }^{(P N)} \text { and } \\
\text { seismic combination }{ }^{(S E)}\end{array}$} \\
\hline
\end{tabular}

unidirectional movable bearing - direction $\mathrm{x}$
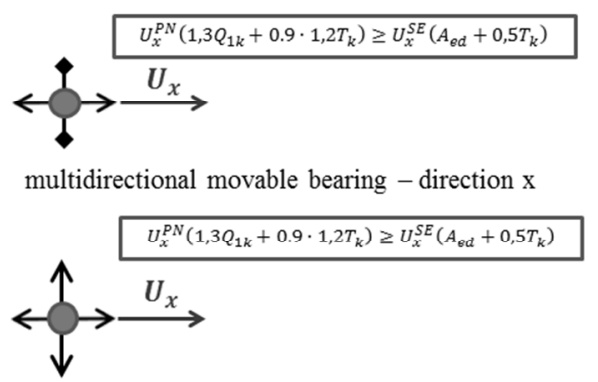

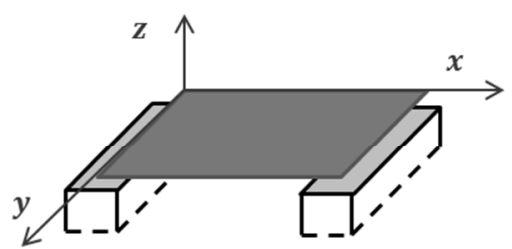

Rys. 5. Schemat obrazujący sposób ustalania kryterialnych wartości przemieszczeń dla łożysk przesuwnych

Fig. 5. A diagram illustrating the method of determining the criterion values of displacements for the condition limiting the displacement of the sliding bearings 


\subsection{The condition of the load-bearing capacity of the supports}

This condition refers to the piers of the portal-frame or wall structure, representing intermediate supports. Two combinations resulting from the design stage were each used for the formulation of this condition, for identifying the limit component in the directions which are longitudinal and perpendicular to the axis of the object (c.f. Fig. 6). Under these conditions, in order to determine the limit component $a_{x, d o p}{ }^{W 6}$, the influence of the following factors were taken into account: the temperature $\left(\boldsymbol{T}_{\boldsymbol{k}}\right)$ and the forces derived from braking or acceleration of vehicles $\left(\boldsymbol{Q}_{1 k}\right)$, together with the forces resulting from the friction of the sliding bearings $(\boldsymbol{E})$. On the other hand, while determining the limit value of the component $a_{y, d o p}{ }^{W 6}$, two combinations of the loads from the design stage were adopted. The first one took into consideration the effect of the wind on the passing vehicles $\left(\boldsymbol{W}_{k s}\right)$, together with the wind pressure applied directly to the supports $\left(\boldsymbol{W}_{k p}\right)$, as well as the forces caused by the friction of the sliding bearings $(\boldsymbol{E})$. In the second combination, in addition to the forces caused by the friction of the sliding bearings $(\boldsymbol{E})$, the forces of the side impacts of the passing vehicles against the components of the roadway $\boldsymbol{U}_{\boldsymbol{k} \boldsymbol{d}}$ were taken into account.

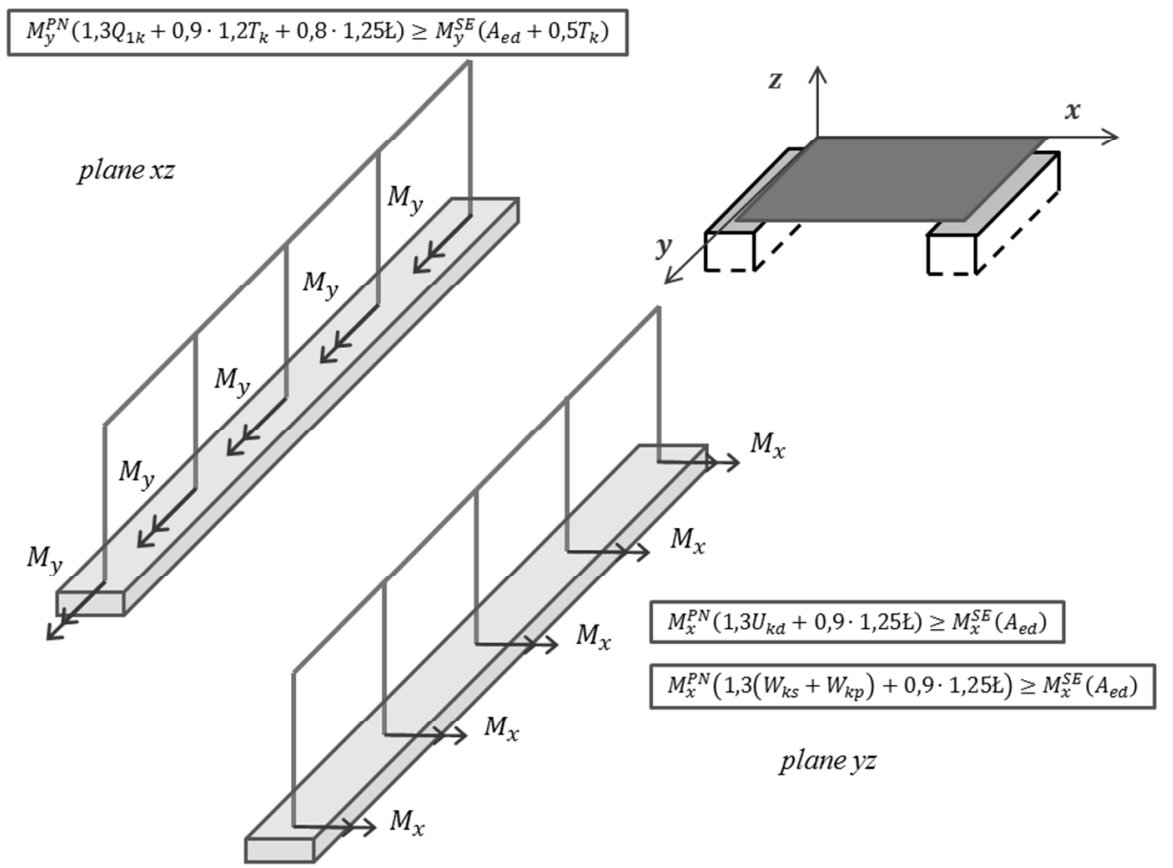

Rys. 6. Schemat obrazujący sposób ustalania kryterialnych wartości podporowych momentów zginających dla warunku nośności podpór

Fig. 6. A diagram illustrating the method of determining the criterion values of the supporting bending moments for the condition of the load-bearing capacity of the supports 
Tabela 6. Zestawienie parametrów przyjmowanych do obliczeń w ocenie odporności dynamicznej dla warunku nośności podpór

Table 6. A list of the parameters adopted for the calculations in assessing the dynamic resistance for the condition of the load-bearing capacity of the supports

\begin{tabular}{|c|c|c|}
\hline \multicolumn{3}{|c|}{ Horizontal direction- $x$ (parallel to the axis of the object) } \\
\hline \multicolumn{3}{|l|}{ The combination of design stage by [11and 15] } \\
\hline \multicolumn{2}{|l|}{$\begin{array}{l}\text { basic load: braking and acceleration forces of car fleet } Q_{l k} \\
\text { additional loads: } \\
\text { - thermal load of span } \boldsymbol{T}_{k} \\
\text { - frictional forces in the bearings } \boldsymbol{E}\end{array}$} & $0,9 \cdot 1,2 T_{k}+0,8 \cdot 1,25 \succeq$ \\
\hline \multicolumn{3}{|l|}{ Corresponding seismic combination by [12 and 13$]$} \\
\hline \multicolumn{3}{|l|}{$A_{e d}+0,5 T_{k}$} \\
\hline \multicolumn{3}{|l|}{ The final form of the condition } \\
\hline \multicolumn{3}{|c|}{$M_{y}^{P N}\left(1,3 Q_{1 k}+0,9 \cdot 1,2 T_{k}+0,8 \cdot 1,25 €\right) \geq M_{y}^{S E}\left(A_{e d}+0,5 T_{k}\right)$} \\
\hline \multicolumn{3}{|c|}{ Horizontal direction- $x$ (parallel to the axis of the object) } \\
\hline \multicolumn{3}{|c|}{ The combination of design stage by [11 and 15] } \\
\hline \multicolumn{2}{|l|}{$\begin{array}{l}\text { Option } 1 \\
\text { basic loads: } \\
\text { - wind load acting on the vehicle fleet } \boldsymbol{W}_{k s} \\
\text { - wind load acting on supports } \boldsymbol{W}_{k p} \\
\text { additional loads: } \\
\text { - frictional forces in the bearings } \mathbf{L} \\
\end{array}$} & $\begin{array}{l}1,3\left(W_{k s}+W_{k p}\right)+0,9 \\
\cdot 1,25 €\end{array}$ \\
\hline \multicolumn{2}{|c|}{$\begin{array}{l}\text { Option } 2 \\
\text { basic load: the forces of a side impact of the elements of the bridge } \boldsymbol{U}_{\boldsymbol{k} \boldsymbol{d}} \\
\text { additional loads: frictional forces in the bearings } \boldsymbol{E}\end{array}$} & $1,3 U_{k d}+0,9 \cdot 1,25 €$ \\
\hline \multicolumn{3}{|l|}{ Corresponding seismic combination by [12 and 13] } \\
\hline Option 1 & & $\bar{A}_{\text {ed }}$ \\
\hline Option 2 & & $A_{e d}$ \\
\hline The final form of the condition for Option 1 & $M_{x}^{P N}(1$ & $\begin{array}{c}\left.\left.-W_{k p}\right)+0,9 \cdot 1,25 €\right) \\
\geq M_{x}^{S E}\left(A_{e d}\right)\end{array}$ \\
\hline The final form of the condition for Option 2 & $M_{x}^{P N}(1,3 L$ & $9 \cdot 1,25 €) \geq M_{x}^{S E}\left(A_{e d}\right)$ \\
\hline \multicolumn{3}{|c|}{$\begin{array}{l}G_{k, i}-\text { self-weight structural components of the bridge and equipment } \\
A_{e d}-\text { design value of the seismic impact } \\
T_{k}-\text { characteristic value of the thermal load of the span } \\
Q_{i k} \text { - characteristic value of the load caused by forces of braking or acceleration of the rolling stock } \\
W_{k s}-\text { characteristic value of the wind load acting on the vehicle fleet } \\
W_{k p} \text { - characteristic value of the wind load acting on supports } \\
\mathrm{E} \text { - characteristic value of the frictional forces in the bearings } \\
U_{k d}-\text { characteristic value of the forces of a side impact of the elements of the bridge } \\
M^{P N}, M^{S E}-\text { bending moments determined for the combination of design stage }{ }^{\left({ }^{P N}\right)} \text { and seismic combination } \\
(S E)\end{array}$} \\
\hline
\end{tabular}

\section{Calculation results}

The object of the research was a three-span reinforced concrete flyover bridge. It consisted of three spans with the length of $16.0 \mathrm{~m}$, the width of $10.0 \mathrm{~m}$ and the height of $0.8 \mathrm{~m}$. The intermediate supports were two reinforced concrete portal frames consisting of three piers with the dimensions of $0.8 \mathrm{~m} \mathrm{x} 0.7 \mathrm{~m} \mathrm{x}$ $6.0 \mathrm{~m}$ and the bridge seat with the dimensions of $1.0 \mathrm{~m} \times 0.6 \mathrm{~m} \times 10.0 \mathrm{~m}$. The concrete from which the span was made was characterized by the value of the 
Young's modulus of $\mathrm{E}=30 \mathrm{GPa}$. The modulus of elasticity of the support frame was: $\mathrm{E}=29 \mathrm{GPa}$ (for beams) and $\mathrm{E}=37 \mathrm{GPa}$ (for pillars) respectively. In all cases, Poisson's ratio was 0.2. Fig. 4.1 illustrates the diagram of the structure and the bearings.

The static and dynamic analyses were performed in ABAQUS Standard program using the interface (ASI-Abaqus Scripting Interface [1]), which is the extension of the Python language.

The beam-and-slab digital model of the structure was created (c.f. Fig. 7). In the model used elements of type B31 for beams elements (columns and beams of support frame) and S4R for spans [1].

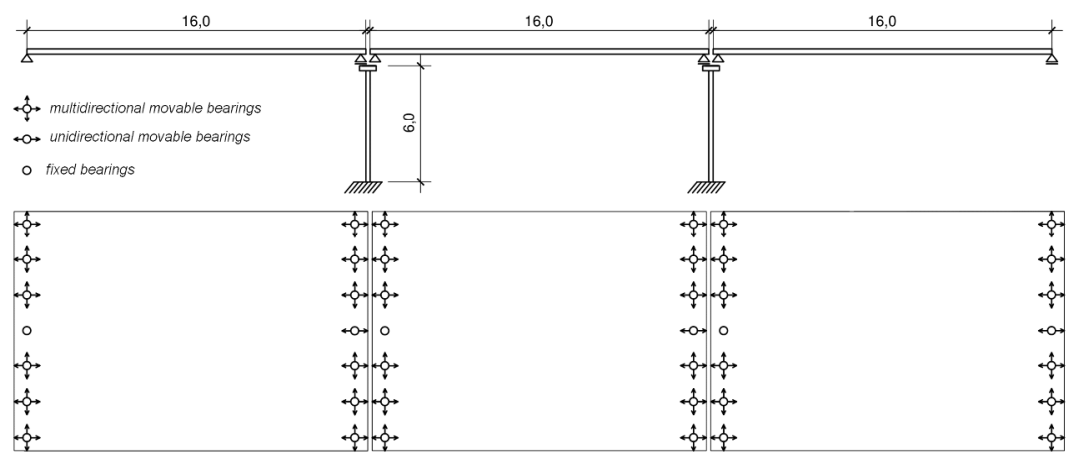

Rys. 7. Schemat przedstawiający geometrię obiektu i rozmieszczenie łożysk

Fig. 7. A diagram demonstrating the geometry of the structure and the location of the bearings

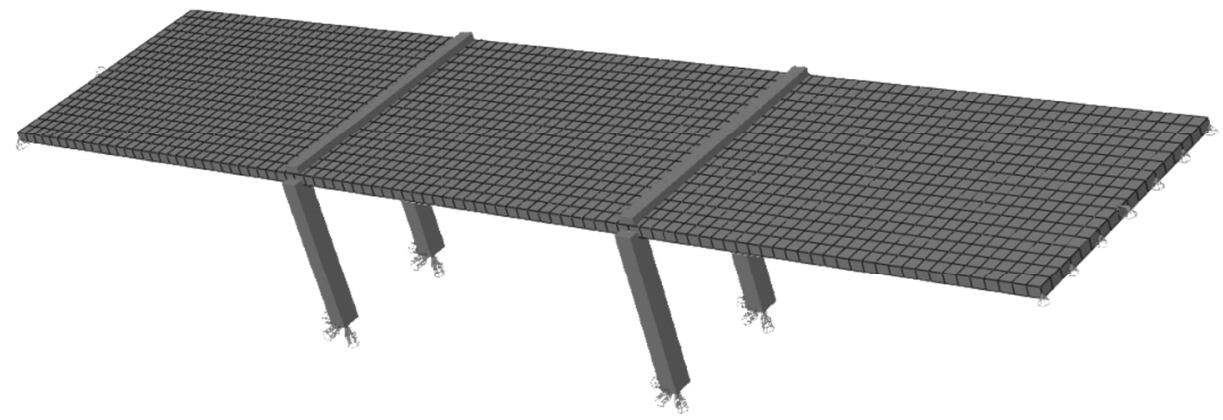

Rys. 8. Model numeryczny wiaduktu

Fig. 8. The numerical model of the flyover bridge

The dynamic analysis was performed by the response spectrum method [2, 7]. The normalized, elastic response spectrum for the ground B was adopted as the dynamic excitation [16]. This load has been applied to all support of the analyzed object, that is, to the foundations of the intermediate pillars and the zone of the support of the spans on the abutments. Such an approach, in accordance with the adopted criteria of assessing the resistance (c.f. Tables 1 to 6), allowed for 
the identification of the limit values of the components of the vector of the acceleration of ground vibrations. In the calculations, according to [14], the damping coefficient $\xi=0.05$ was used. Dynamic calculations were made using the Rayleigh damping model [3, 9].

The effects of the excitation were analyzed separately for the three directions $(x-$ the direction longitudinal to the axis of the object, $y-$ the direction perpendicular to the axis of the object, $z$ - the vertical direction). The summation of the contributions from the individual modes of vibration was carried out according to [14] using the method of CQC (Complete Quadratic Combination [2]).

Figure 9 shows the first six forms of eigenmodes and corresponding frequencies. Finally, the first 20 eigenmodes were used for the calculation by the spectral response method.
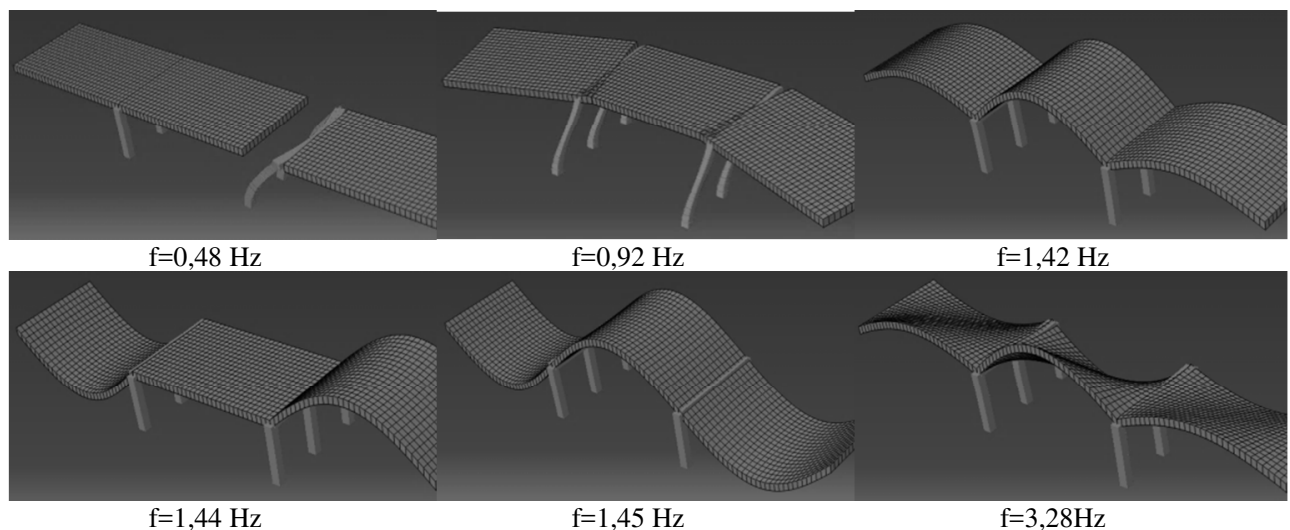

Rys. 9. Sześć pierwszych postaci drgań własnych obiektu i odpowiadające im częstotliwości

Fig. 9. The first six eigenmodes of analyzed object and corresponding frequencies

The performed analyses resulted in the limit values of the individual components of the vector of the acceleration of ground vibrations for each of the conditions of the assessment of the dynamic resistance presented in Chapter 3. The obtained results were contained in Table 7. These values are components of a design acceleration that is a scaling factor using in the standard response curves according to [16]. They were set individually for each condition. This consisted of multiple numerical simulations for different values of the ground vibration acceleration components until the equilibrium with the criterion values of the combination from the design stage was determined.

These data demonstrate that the proposed methodology, in addition to the final set of the limit values of the components of the acceleration of ground vibrations, allows the studied structure to to be subjected to the additional sensitivity analysis with respect to its structural components. Such information 
may contribute to the increase in the effectiveness of potential construction interference in the object because it identifies the most sensitive elements of its load-bearing structure. In the case of the analyzed object, these sensitive elements are the pillars of the support frames, for which the lowest limit values of the components of ground vibrations in the horizontal plane were obtained, perpendicular to the axis of the object $\left(a_{y, d o p}{ }^{W 6-1}=0,47\left[\mathrm{~m} / \mathrm{s}^{2}\right]\right.$ and $a_{y, d o p}{ }^{W 6-2}=$ $\left.0,48\left[\mathrm{~m} / \mathrm{s}^{2}\right]\right)$. It should be noted, that the sensitivity of the structure is closely related to its geometry and the material parameters of its load-bearing elements. Therefore, when analyzing the resistance of the structure of other geometric and material features, it should be expected that these indications will change.

Tabela 7. Zestawienie dopuszczalnych wartości składowych przyspieszeń drgań gruntu wyznaczonych wg kryteriów podanych w rozdziale 3.

Table 7. A list of the limit values of the components of the acceleration of ground vibrations determined according to the criteria specified in Chapter 3

\begin{tabular}{|c|c|c|c|c|c|}
\hline \multirow{2}{*}{$\begin{array}{c}\text { Condition } \\
\text { number }\end{array}$} & \multirow{2}{*}{$\begin{array}{c}\text { Direction of } \\
\text { action } \\
\end{array}$} & \multirow{2}{*}{ Option } & \multicolumn{3}{|c|}{ Limit values of the vector components of ground acceleration } \\
\hline & & & $a_{x, d o p}\left[\mathrm{~m} / \mathrm{s}^{2}\right]$ & $a_{y, d o p}\left[\mathrm{~m} / \mathrm{s}^{2}\right]$ & $a_{z, d o p}\left[\mathrm{~m} / \mathrm{s}^{2}\right]$ \\
\hline 1 & $\mathrm{Z}$ & - & & & 1,10 \\
\hline \multirow{3}{*}{2} & $\mathrm{Z}$ & - & & & 0,87 \\
\hline & $\mathrm{X}$ & - & 0,97 & & \\
\hline & $\mathrm{Y}$ & - & & 1,09 & \\
\hline 3 & $\mathrm{Z}$ & - & & & 0,63 \\
\hline 4 & $\bar{Z}$ & - & & & 0,85 \\
\hline 5 & $\mathrm{X}$ & - & 0,93 & & \\
\hline \multirow{3}{*}{6} & $\mathrm{X}$ & - & 1,28 & & \\
\hline & \multirow{2}{*}{$\mathrm{Y}$} & 1 & & 0,47 & \\
\hline & & 2 & & 0,48 & \\
\hline \multicolumn{3}{|c|}{ The final resistance of the object } & 0,93 & 0,47 & 0,63 \\
\hline
\end{tabular}

Table 8 shows the values of measures describes the response of the structure for the specified permissible acceleration components of ground vibrations. These results were compared with the effects from the load combinations adopted at the design stage. Combinations from the design stage and the seismic combination do not occur simultaneously but are disconnected computational situations [12].

Therefore, for the conditions 3, 5 and $6(W-I)$, the seismic impact generates a structure response equal to that obtained at the design stage. In other cases, the structure response for the seismic combination is less than the corresponding effects from the design stage. 
Tabela 8. Porównanie wartości miar opisujących odpowiedź konstrukcji dla określonych dopuszczalnych składowych przyspieszenia drgań gruntu $\left(a_{x, \text { dop }}, a_{y, d o p}, a_{z, d o p}\right) \mathrm{z}$ wynikami od kombinacji $\mathrm{z}$ etapu projektowania

Table 8. Comparison of values of measures describes the response of the structure for the specified permissible acceleration components of ground vibration $\left(a_{x, d o p}, a_{y, d o p}, a_{z, d o p}\right)$ with corresponding results of combinations from design stage

\begin{tabular}{|c|c|c|}
\hline Condition description & $\begin{array}{l}\text { Results for the combinations adopted at the } \\
\text { design stage }\end{array}$ & $\begin{array}{l}\text { Results for seismic combina- } \\
\text { tion when accepting the } \\
\text { obtained values } a_{x, \text { dop }}, a_{y, d o p} \\
a_{z, \text { dop }}\end{array}$ \\
\hline \multirow[t]{3}{*}{$\begin{array}{l}\text { 1.The strength condition } \\
\text { of the load-bearing } \\
\text { capacity of the spans }\end{array}$} & $\begin{array}{c}\text { Extreme values of bending moment in the } \\
\text { spans }\end{array}$ & $\begin{array}{l}\text { Corresponding values of } \\
\text { bending moments in the } \\
\text { spans }\end{array}$ \\
\hline & $M^{P N}\left(\sum_{i=1}^{m} 1,2 G_{k, i}+1,3 Q_{T S}\right)$ & $M^{S E}\left(\sum_{i=1}^{m} G_{k, i}+A_{e d}\right)$ \\
\hline & $1,81 \mathrm{MNm}$ & $1,37 \mathrm{MNm}$ \\
\hline $\begin{array}{l}\text { 2.The condition of the } \\
\text { load-bearing capacity of } \\
\text { the fixed bearings and } \\
\text { the bearings sliding in } \\
\text { one direction (leading) }\end{array}$ & Extreme values of forces in the bearings & $\begin{array}{l}\text { Corresponding values of } \\
\text { forces in the bearings }\end{array}$ \\
\hline \multirow[t]{2}{*}{$\mathrm{X}$ - direction } & $R^{P N}\left(1,3 Q_{1 k}+0.9 \cdot 1,2 T_{k}\right)$ & $R^{S E}\left(A_{e d}+0,5 T_{k}\right)$ \\
\hline & $12,85 \mathrm{MN}$ & $12,56 \mathrm{MN}$ \\
\hline \multirow[t]{2}{*}{ Y - direction } & $R^{P N}\left(1,3 U_{k d}+0,9 \cdot 1,2 W_{k s}\right)$ & $R^{S E}\left(A_{e d}\right)$ \\
\hline & $0,126 \mathrm{MN}$ & $0,05 \mathrm{MN}$ \\
\hline \multirow[t]{2}{*}{$\mathrm{Z}$ - direction } & $\left.1,2 G_{k, i}+1,3 Q_{T S}\right)$ & $R^{S E}\left(\sum_{i=1}^{m} G_{k, i}+A_{e d}\right)$ \\
\hline & $5,22 \mathrm{MN}$ & $4,93 \mathrm{MN}$ \\
\hline \multirow{3}{*}{$\begin{array}{l}\text { 3.The condition of the } \\
\text { contact between the } \\
\text { support and the span }\end{array}$} & The vertical pressing force on the bearing & $\begin{array}{l}\text { Tearing force the spans from } \\
\text { bearings }\end{array}$ \\
\hline & $R^{E N}\left(\sum_{i=1}^{m} 0,9 G_{k, i}\right)$ & $R^{S E}\left(A_{e d}\right)$ \\
\hline & $3,76 \mathrm{MN}$ & $3,76 \mathrm{MN}$ \\
\hline \multirow[t]{3}{*}{$\begin{array}{l}\text { 4.The condition limiting } \\
\text { the friction force for the } \\
\text { sliding bearings }\end{array}$} & $\begin{array}{c}\text { Extreme values of friction forces in the } \\
\text { sliding bearings }\end{array}$ & $\begin{array}{c}\text { Corresponding values of } \\
\text { friction forces in the sliding } \\
\text { bearings }\end{array}$ \\
\hline & $T^{P N}\left(\sum_{i=1}^{m} 1,2 G_{k, i}+1,3 Q_{T S}\right)$ & $T^{S E}\left(\sum_{i=1}^{m} G_{k, i}+A_{e d}\right)$ \\
\hline & $5,22 \mathrm{MN}$ & $4,95 \mathrm{MN}$ \\
\hline \multirow{3}{*}{$\begin{array}{l}\text {.The condition limiting } \\
\text { the sliding of the sliding } \\
\text { bearings }\end{array}$} & $\begin{array}{c}\text { Extreme values of sliding of the sliding } \\
\text { bearings }\end{array}$ & $\begin{array}{l}\text { Corresponding values of } \\
\text { sliding of the sliding bearings }\end{array}$ \\
\hline & $U^{P N}\left(1,3 Q_{1 k}+0.9 \cdot 1,2 T_{k}\right)$ & $U^{S E}\left(A_{e d}+0,5 T_{k}\right)$ \\
\hline & $21,7 \mathrm{~mm}$ & $21,7 \mathrm{~mm}$ \\
\hline $\begin{array}{l}\text { 6.The condition of the } \\
\text { load-bearing capacity of } \\
\text { the supports }\end{array}$ & $\begin{array}{l}\text { Extreme values of bending moments in the } \\
\text { support zones }\end{array}$ & $\begin{array}{l}\text { Corresponding values of } \\
\text { bending moments in the } \\
\text { support zones }\end{array}$ \\
\hline \multirow[t]{2}{*}{$\mathrm{X}$ - direction } & $M_{y}^{P N}\left(1,3 Q_{1 k}+0,9 \cdot 1,2 T_{k}+0,8 \cdot 1,25 €\right)$ & $M_{y}^{S E}\left(A_{e d}+0,5 T_{k}\right)$ \\
\hline & $1,02 \mathrm{MNm}$ & $0,74 \mathrm{MNm}$ \\
\hline \multicolumn{3}{|l|}{$\mathrm{Y}$ - direction } \\
\hline \multirow[t]{2}{*}{ Variant - I (V-I) } & $M_{x}^{P N}\left(1,3\left(W_{k s}+W_{k p}\right)+0,9 \cdot 1,25 €\right)$ & $M_{x}^{S E}\left(A_{e d}\right)$ \\
\hline & $0,085 \mathrm{MNm}$ & $0,085 \mathrm{MNm}$ \\
\hline \multirow[t]{2}{*}{ Variant - II (V-II) } & $M_{x}^{P N}\left(1,3 U_{k d}+0,9 \cdot 1,25 Ł\right)$ & $M_{x}^{S E}\left(A_{e d}\right)$ \\
\hline & $0,079 \mathrm{MNm}$ & $0,077 \mathrm{MNm}$ \\
\hline
\end{tabular}




\section{Summary and conclusions}

The proposed method for the assessment of the dynamic resistance of bridge structures presented in this study allows one to determine an acceptable safety margin for the existing structure in the case of the occurrence of mining tremors. Moreover, this procedure allows one to determine the limit values of the components of the acceleration of ground vibrations even if there is no information on the reinforcement of the load-bearing elements, or on the loadbearing capacity of the bearings in the blocked directions.

The analysis of the obtained results also provides an opportunity to assess the sensitivity of the individual structural components to dynamic loads induced by mining tremors. Such additional information may be useful in a decisionmaking process regarding potential construction interference, aimed to adapt the structure to carry additional loads caused by mining tremors in a specific area.

The article was prepared as part of the statutory research of AGH University of Science and Technology No. 11.11.150.005

\section{References}

[1] ABAQUS 2011. ABAQUS Documentation. Dassault Systemes. Providence, RI, USA.

[2] Chmielewski T., Zembaty Z. 2006: Podstawy dynamiki budowli.(The rudiments of the dynamics of structures). Arkady.

[3] Chowdhury I., Dasgupta Shambhu P. 2003: Computation of Rayleigh damping coefficients for large systems. The Electronic Journal of Geotechnical Engineering.

[4] Ciurej H., Rusek J. 2006: Metodyka oceny odporności dynamicznej wybranych obiektów mostowych na terenie LGOM. Czasopismo Techniczne. Budownictwo, 2006, 103: $31-57$.

[5] Lewandowski R. 2006: Dynamika konstrukcji budowlanych. Wydawnictwo Politechniki Poznańskiej.

[6] Madaj A., Wołowicki W. 2009: Podstawy projektowania budowli mostowych. WKŁ. Warszawa.

[7] Majcherczyk T., Tatara T., Wałach D. 2005: Wpływ drgań powierzchniowych wywołanych wstrząsami górniczymi na konstrukcje wież szybowych. Miesięcznik WUG, 6, 130.

[8] Pachla F., Tatara T. 2015: Odporność dynamiczna obiektów infrastruktury drogowej i sportowej na wybranym obszarze GZW. Przegląd Górniczy 71.10: 42-50.

[9] Spears R. E., Jensen S. R. 2012: Approach for selection of Rayleigh damping parameters used for time history analysis. Journal of pressure vessel technology, 134.6: 061801.

[10] Szczygieł J. 1978: Mosty z betonu zbrojonego i sprężonego. Wydawnictwa Komunikacji i Łączności.

[11] PN-B-02000:1982 Obciążenia budowli - Zasady ustalania wartości.

[12] PN-EN 1990:2004. Eurokod. Podstawy projektowania konstrukcji. 
[13] PN-EN 1991-2:2007. Eurokod 1. Oddziaływania na konstrukcje. Część 2: Obciążenia ruchome mostów.

[14] PN-EN-1998-2:2006. Eurokod 8. Projektowanie konstrukcji poddanych oddziaływaniom sejsmicznym. Część 2: Mosty.

[15] PN-S-10030:1985 Obiekty mostowe. Obciążenia.

[16] Zembaty Z., Kokot S. 2014: Adaptacja sejsmicznych norm projektowania konstrukcji do ujęcia wpływu wstrząsów górniczych na budowle. Przegląd Górniczy, 70.

\section{PROPOZYCJA OCENY ODPORNOŚCI DYNAMICZNEJ ISTNIEJĄCYCH WIADUKTÓW DROGOWYCH O ŻELBETOWEJ KONSTRUKCJI PEYTOWEJ NA WPEYW WSTRZĄSÓW GÓRNICZYCH}

\section{Streszczen i e}

W pracy przedstawiono propozycję metody oceny odporności dynamicznej istniejących wiaduktów drogowych o konstrukcji płytowej poddanych wstrząsom górniczym. W tym celu sformułowano sześć kryteriów pozwalających wyznaczyć największe dopuszczalne wartości składowych przyspieszeń drgań gruntu $\left(a_{x, \text { dop }}, a_{y, \text { dop }}, a_{z, \text { dop }}\right)$. W ramach poszczególnych kryteriów odniesiono się do najbardziej newralgicznych elementów konstrukcyjnych, dla których skonstruowano warunki wytężeniowe i kinematyczne, odzwierciedlające zachowanie się konstrukcji pod wpływem wzbudzenia dynamicznego wywołanego wstrząsem górniczym. Dopuszczalny zakres pracy konstrukcji został ustalony na drodze porównania efektów od kombinacji obciążeń przyjmowanych na etapie projektowania z kombinacją sejsmiczną ujętą $\mathrm{w}$ [12]. W zakresie analizy dynamicznej wykorzystano Metodę Spektrum Odpowiedzi z uwzględnieniem wytycznych dotyczących adaptacji Eurokodu 8 do obliczeń obiektów budowlanych na wpływy wstrząsów górniczych [16]. Finalnie, zgodnie z przyjętą procedurą, przeprowadzono obliczenia i zaprezentowano wyniki dla przykładowego wiaduktu drogowego o żelbetowej konstrukcji płytowej.

Keywords: wiadukty, konstrukcje żelbetowe, odporność dynamiczna, wpływy górnicze, wstrząsy

Przestano do redakcji: $5.12 .2016 r$.

Przyjęto do druku: 31.03 .2017 r. 